\title{
Exhibits: Illegitimate Children of Academic Libraries?
}

\section{Laurel G. Bowen and Peter J. Roberts}

\begin{abstract}
Academic libraries requiring evidence of scholarship and publication for faculty promotion and tenure often regard exhibits as worthwhile activities, but not intellectually rigorous ones that meet accepted academic standards. This is not necessarily the view of archivists and museum professionals, who believe exhibits can be important interpretive ventures based on original research which can make a major contribution to scholarship. To demonstrate that exhibits are a fully legitimate scholarly enterprise, this paper compares the intellectual and creative process of producing a scholarly article with that of preparing an exhibit. Academic concerns about exhibits as scholarship are considered, and advantages of exhibits as a form of scholarly communication are suggested.
\end{abstract}

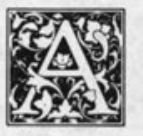

cademic libraries, particularly those that require research as a criterion for promotion and tenure, appear to have ambivalent attitudes toward exhibits. While few academic librarians would label exhibits as a frivolous activity, and while many point out their instructional and promotional value, most librarians do not regard exhibits as an intellectually rigorous activity on a par with producing articles for professional publications. Although considered worthwhile, they are not valued as an essential function, as reference or collection development are, and their creation is not viewed as a fully legitimate scholarly enterprise. Exhibits are the illegitimate children of academic libraries: while we enjoy having them around, they may not quite belong in the family, and we may be uncomfortable about the circumstances surrounding their creation.

The literature of the library profession reflects the prevalence of these attitudes. Authors refer to widely held views of exhibits that equate them with "merely a decorator's task," little more than "displays to dress up the library or add a little color," "an added burden and a necessary evil" that the staff approaches "grudgingly."1,2 These authors try to provide some legitimacy to exhibit preparation by exploring the planning, design, and execution of exhibits; the role of exhibits in education, public relations, and outreach programs; and the experience of mounting exhibits in particular libraries. $^{3}$ There are even tantalizing indications that some authors sense the power and innate respectability of exhibits as "a scholarly effort," something that is "important for professional development," an interpretive tool that can "present the vast resources we control" to "open up new lines of sight into an unlimited array of topics and genres, ideas and movements, societies and individuals."4,5,6 This occasional praise notwithstanding, the library literature that treats exhibits seriously still views this work as "a secondary function of academic libraries," and it

Laurel G. Bowen and Peter J. Roberts are at William Russell Pullen Library, Georgia State University, Atlanta, Georgia 30303. 
separates the "core functions" of a library from "our responsibilities as a museum" [italics added] - a nonlibrary profession. ${ }^{78}$ The library literature lacks a perspective that fully explores the intellectual and creative process of producing an exhibit. ${ }^{9}$

The archival, museum, and history professions are more receptive to the idea of exhibits as a scholarly enterprise, and the attitude of these professions toward exhibits is more positive than that of academic librarians. Archival literature describes exhibits as "worthwhile," "a major component in public outreach programs," "important and ... integral to the mission of the institution," and "a positive decision."10,11 Distinctions are made between "display-case" or "mini-exhibits" and those that "grow out of extensive study of primary source materials" and "make a major contribution to scholarship." 12,13 Not only are the more substantive exhibits based on in-depth research, but they are "a form of opinion about the past" and "an important interpretive venture" that can "provide a visual counterpart to, and relief from, textbooks, scholarly publications, and other writings."14,15,16,17 Archivists and historians regard exhibits in this respect as a type of publication, and exhibit reviews have appeared with the book review sections of the journals of both the Society of American Archivists and the Organization of American Historians. ${ }^{18}$

Museum professionals take this approach one step further. Not only do the best exhibits reflect familiarity with current scholarship on a subject and make a contribution to a field of study, but the way exhibits achieve their purpose has also long been an appropriate subject of study. ${ }^{19}$ Exhibits are the primary means by which museums perform their mission: to educate the public. It is not surprising, then, that the professional literature seeks scientific ways to evaluate the effectiveness of exhibits by examining visitors' responses to different design elements. ${ }^{20}$ The literature addresses all sides of the equation: the visitor-his or her attitudes, learning ability, and behavior; the exhibit-de- signing one that will attract, engage, and teach the visitor; and methods of predictably controlling interactions between the two. The desired result is a change in attitude or behavior-learning, in other words. Museums advocate points of view that universities seem to be adopting: the importance of adult education, full acceptance of a multimedia approach to teaching, and an emphasis on making research and scholarship more accessible to the public.

Is the intellectual and creative process of preparing an exhibit as rigorous as that required to produce a scholarly article? The process of writing an article can be outlined as follows:

- Select a topic.

- Locate and explore the sources.

- Develop a theme or thesis.

- Evaluate and select material to illustrate and interpret the theme.

- Assemble and present material in a manner that will best convey the theme or thesis.

- Interpret the theme or thesis.

- Publish the results.

Academic libraries, particularly those that require research as a criterion for promotion and tenure, appear to have ambivalent attitudes toward exhibits.

This is the same process that one follows in producing an exhibit. In fact, the process of creating an exhibit can be even more demanding, since a wider variety of audiences, techniques, and media comes into play.

The intellectual rigors of producing library journal articles vary-bibliographies, surveys, success stories, interpretations of theory, and arguments for changed practices may not require the same amount of original thought. The same is true of exhibits. In producing "displays," for example, the process outlined above is not only greatly abbreviated but executed more superficially than that involved in preparing an interpretive presentation. Eye-catching arrangements of similar objects from a 
collection with minimal interpretation of their significance have a place in an exhibits program, but the greatest prestige is reserved for "exhibits that explore their subjects in some depth and make original contributions to their fields." ${ }^{21}$

When writing an article for a professional journal, there is little uncertainty about who is expected to read the publication. The audience is a fixed and known entity-namely, one's professional colleagues. Exhibits are more complex in this regard, since an audience must be defined and created. This is a critical task because the audience is the exhibit's reason for being. Considerable effort is expended to develop a profile of the target audience, and, once the exhibit is undertaken, to attract a more diverse audience through promotional activities and coordinated events. ${ }^{22}$ The audience's reaction is of primary importance to the exhibit designer, who must use a variety of techniques to persuade visitors to become involved in the exhibit. Designers usually prefer interactive or participatory techniques to those that treat the audience as a passive receptor of information (like a lecture attendee or a reader of a book). ${ }^{23}$ Mounting an exhibit, unlike publishing an article, is not the final act; observation of the audience's reactions and an evaluation of these responses are also considered essential components of the process. ${ }^{24}$

The early stages of preparing a journal article or an exhibit are the foundation upon which the whole enterprise rests, and the process is very similar. Selecting a topic, locating and examining the sources, and developing a theme or thesis is a process in which interest, originality, accidental discovery, and persistence all play a role. Researching for an exhibit can be significantly more challenging, however, for two reasons. First, since an exhibit "raises issues visually so that they can be grasped immediately," a potentially interesting theme will fail if it cannot be presented visually. ${ }^{25} \mathrm{In}$ addition, the universe of sources explored for exhibits includes not just textual documents but also objects, images, sounds, and everything else that falls within the range of experience and perception. Nontraditional sources may add another dimension to our current understanding of events or issues and can completely overturn accepted views. In the words of one authority, "One of the great challenges of exhibiting is to inspire the writers of books to make more extensive use of a wider range of sources." ${ }^{26}$

Once an author or exhibit preparer has identified a topic and developed a point of view based on a study of the sources, he or she then begins the process of evaluating and selecting evidence to support this thesis. While authors use words to marshall support for their arguments, an exhibitor must find just the right physical evidence to do the same job. ${ }^{27}$ This is one of the most difficult and significant components of exhibit preparation. Additional background reading is often required, and attention to historical accuracy and objectivity are important..$^{28}$ Informed judgment, skill in keeping track of the location of potential exhibit items, and a sensitivity to the visual impact, documentary value, and symbolic importance of materials are all essential in what frequently becomes a lengthy search process. ${ }^{29}$ While the success of a journal article depends primarily on the author's skill in presenting reasoned arguments, a powerful exhibit does not appeal just to the intellect but must be emotionally and aesthetically satisfying as well. Using an appropriate mix of materials-textual documents, graphics, and three-dimensional objects-to interpret a theme will attract viewers' attention, draw them into the subject, and encourage them to see new relationships by the way materials are juxtaposed. ${ }^{30}$ Exhibitors are constantly alert to the interpretive possibilities of the materials they survey, as well as to the physical condition of the materials. ${ }^{31}$ Including too much in an exhibit can overwhelm and distract a viewer, so the exhibit preparator must be particularly rigorous in selecting the most significant items that will illustrate the theme in a visually interesting manner.

The process of evaluating and selecting evidence frequently encourages an 
author or exhibitor to refine his or her thematic concept. With this new understanding of their focus, authors and exhibitors structure a story or argument using their evidence, presenting it clearly and in a well-organized manner. Authors' tools are words, ideas, and thoughts-they communicate verbally. Exhibit designers express themselves visually - they quite literally build a structure that will convey the theme. The designer interprets a subject by coordinating the selected objects with an idea and by presenting them in a style that fosters study and comparison..$^{32}$ An author uses a logical progression of ideas to make the case. A designer groups and lays out documents, images, and artifacts in a manner that invites viewers to see relationships. He or she uses the interplay of color, light, and texture to create mood, while the size, shape, format, and placement of items determine emphasis in the composition. The designer also uses verbal cues in an exhibit; labels, which are part of an overall "script" or story line, explain the significance of the materials selected and establish the context in which they are presented. Unlike journal articles, the text in an exhibit does not carry the full interpretive weight of the exhibit. Labels are extremely concise and are intended only to orient viewers, stimulate interest, and present basic concepts. Judgments about their physical appearance and placement are thus as important as content. ${ }^{33}$

Whether preparing a journal article or exhibit, similar intellectual and creative processes are used in choosing a topic, exploring sources, and evaluating, selecting, and presenting material to effectively interpret a theme. This process ends when authors or exhibit preparers place a concrete product-the results of their research and interpretation-in a public forum to be judged for quality and effectiveness by an audience. This is publication-the act of making public. The final product for a journal article is a printed text addressed to colleagues who speak the same professional language. An exhibit is a more complex final product. It is an interwoven com- position of printed words, images, objects, and occasionally sounds, that is presented for the critical appraisal of not just colleagues but the public at large. An exhibit is judged by the uninitiated as well as the initiated and must be comprehensible to both. As a product, it is the result of both research and creative activity and thus is a close cousin to such artistic endeavors as musical and theatrical performances. An exhibit appeals to intellect, emotion, and the aesthetic sense. It is not merely a lifeless product-it is a sensory experience and an entertaining event as well.

While the success of a journal article depends primarily on the author's skill in presenting reasoned arguments, a powerful exhibit does not appeal just to the intellect but must be emotionally and aesthetically satisfying as well.

Exhibits that re-create an environment for the viewer have the potential for making a significant impact on the public and the academic community. The Atlanta Heritage Row exhibit helps visitors experience the claustrophobia, fear, and uncertainty of a family hiding in their basement during the Union siege of Atlanta. Audio and visual effects are particularly striking as the visitor stands in a low, cramped area listening to a young girl read from a contemporary diary, accompanied by the steady thudding of shells and occasional flashes of red light. A simpler but powerfully moving component of the same exhibit combines photographs of segregated lunch counters and hooded Ku Klux Klansmen, a pastor's pulpit, and a recording of Martin Luther King, Jr., proclaiming, "I have a dream...."

The use of sound and moving images in an exhibit can be particularly effective. Many books have been written explaining the power and popular appeal of Adolf Hitler, for example, but an exhibit using vintage German newsreels can instantly and unforgettably demon- 
strate his charisma and the wild enthusiasm he provoked among his followers.

Homelessness is also a topic explored by numerous articles and statistical studies but never more meaningfully than in the Smithsonian's Etiquette of the Undercaste, an interactive maze that a visitor enters lying in a morgue drawer. Audiotape cassette players containing excerpts of real conversations with the homeless lead solitary visitors through simulated experiences in a prostitute's hotel room, a jail cell, reform school, and soup kitchen. The visitors are both audience and performer in this exhibit. They are assaulted by a street world of screeching sirens, pulsating strobe lights, and menacing figures-and then confronted by their own reactions when they see their images in a number of discreetly placed mirrors. ${ }^{35}$

The exhibit's kinship with creative artistic expressions makes it more difficult to evaluate than more traditional scholarship, but we do not lightly dismiss the work of colleagues in art, music, or literature because it is different or difficult to judge.

Like artistic performances, the ephemeral nature of exhibits as events may be a concern, but it is not an insurmountable problem. When exhibits are the result of "substantive original research," efforts are usually made "to publish a record of the information and insights gathered." 36 The exhibit catalog then becomes a permanent reference tool. ${ }^{37}$ Permanence can also be assured by other means. The exhibit can be photographed like any other event and studied later, using the photos as documentary evidence. Notes taken during the research phase of the exhibit can be handled as a manuscript collection and used by other researchers in the library. Like artifacts unearthed during an archaeological excavation, items used during the exhibit (or reproductions of them) can be retained as a group and used by patrons for study. Even if a cat- alog is not published, a record can be maintained of items used in the exhibit and their placement so that the exhibit can be re-created at a later time. ${ }^{38}$ While efforts to provide a lasting record of an exhibit's impact may be part of a striving for permanence in a changing world, it is the exhibit itself (and not the documentation of it) that is the published product of research.

The same procedures that an author employs in producing an article for publication are followed in creating an exhibit. Indeed, at many stages during the process, it is clear that preparing an exhibit is even more demanding than writing an article. If the intellectual and creative rigors of exhibit production are so great, why are most academic institutions uncomfortable granting exhibits the status of a scholarly activity? The exhibit's kinship with creative artistic expressions makes it more difficult to evaluate than more traditional scholarship, but we do not lightly dismiss the work of colleagues in art, music, or literature because it is different or difficult to judge. An exhibit is an entertaining experience. Do we suspect that because it is enjoyable, its creation must not have been rigorous or its purpose not serious? Exhibits appeal to the emotions and senses as well as to the intellect. Do we fear exhibits as tools of manipulation rather than respect them as instruments for teaching?

As the offspring of museums, exhibits treat artifacts and images as objects for serious study. Do we share "the prejudice on the part of learned people on university faculties that only the written or printed word is an intellectually respectable source for research and valid work"? Museums have long known that "objects are as much documents to be read as the printed page." ${ }^{39}$ Bibliographical scholars know this also. ${ }^{40}$ Information is more than just the message conveyed by a text. The physical carriers of ideas-the method of information transmission, the formats in which ideas are expressed-also provide information.

Exhibits use a multimedia approach to communication. Much of our learning today is visual and interactive. When we 
convey the results of our research, are we going to insist on printed text in professional journals and the public reading of text at conferences? Information encountered in this way becomes a sterile commodity when it competes with "learning tools [that] are massive, multicultural, interactive, and visually stunning." ${ }^{\prime 41}$ Will we be satisfied with the passive appreciation of text while multimedia approaches engage all the senses to enhance learning and stimulate personal responses to new knowledge? Will we dismiss a method of conveying information that accommodates different learning styles, that encourages the learner to use facts and ideas we present to create new knowledge on his or her own, and that portrays our work as "appealing, powerful,and moving" ? ${ }^{42}$

\section{Exhibits demonstrate that information} is also packaged in nontextual forms. Effective exhibits are user-friendly; they stimulate interest in a topic and encourage a search for additional information.

Are exhibits merely a useful teaching technique, not a serious research activity? And is teaching what we relegate to second-string faculty? The links between teaching and research are being forged anew. Good teachers are those who are actively involved in research, and major academic institutions are becoming increasingly self-critical for sacrificing teaching on a narrowly defined altar of faculty research. Leading supporters of education are encouraging a more broadminded view of the roles of teaching and research. A new interpretation of information or a presentation of ideas that leads to a new understanding is just as necessary in advancing knowledge as is the discovery of new facts..$^{43}$

As we broaden our concept of knowledge and of the research that reveals it, the value of collaboration across professional and disciplinary boundaries becomes clear. ${ }^{44}$ The process of developing an exhibit has often been a sterling example of cooperative work among curators, subject specialists, designers, editors, conservators, and public relations promoters. ${ }^{45}$ If research benefits from the integration of knowledge and if scholarship suffers from its fragmentation, we should be reaching out across the narrow boundaries of our own profession to adapt insights, techniques, and approaches used in other fields. ${ }^{46}$

"At its best," one author states, "the academic library exhibit is a scholarly effort subject to review by a large audience." ${ }^{47}$ Do we harbor an unacknowledged sense that this audience, which includes students and the general public, might not be as significant as the professional colleagues who read our journal articles? Do we believe that the judgments of this audience are not as valid as those of our colleagues? Academics who receive government grants that support research, collections, and services are discovering that this attitude is self-defeating in the face of growing taxpayer scrutiny of the relevance of work supported by public funds.

Exhibits demonstrate that information is also packaged in nontextual forms. Effective exhibits are user-friendly; they stimulate interest in a topic and encourage a search for additional information. They empower users, enabling them to learn on their own. They provide lifetime learning for people of all ages. These are all concepts that are familiar in a library environment.

Exposure to a variety of design, fabrication, public relations, subject, and other specialists during the preparation of an exhibit encourages us to challenge and refine the assumptions of our own profession, and it promotes an ongoing process of learning, in the best traditions of higher education. Exhibits provide college and university librarians with opportunities to forge links with colleagues in other academic disciplines. Collaboration promotes mutual understanding and allows us to demonstrate the value of our own profession to academia-a profitable exercise if the faculty status of librarians is brought into question. Finally, exhibits provide both 
librarians and other academics with a way to communicate the value of our work to corporate sponsors and the general public, whose financial and moral support is essential to our success.

Exhibits, as a form of scholarly communication, have many values for academic librarians. They allow us to speak in a new language to a wider audience. They encourage an interdisciplinary dialogue with academic colleagues, stimulating new thinking that promotes the advancement of knowledge. Exhibits broaden our view of the sources of information, and they foster awareness of the inextricable link between information and its carrier. Exhibits may be children that academic libraries have adopted from museums, but it is time to welcome them as an integral part of the family.

\section{REFERENCES AND NOTES}

1. Dorothy E. Jones and Mary Grosch, "Exhibits Speak Louder than Words," Technicalities 7 (Sept. 1987): 6.

2. Werner Gundersheimer, "Two Noble Kinsmen: Libraries and Museums," Rare Books and Manuscripts Librarianship 3 (Fall 1988): 100.

3. In addition to the Jones and Grosch article cited above, see the following: Lucy S. Caswell, "Building a Strategy for Academic Library Exhibits," College \& Research Libraries News 46 (Apr. 1985): 165-67; Jane Kemp, "Creating Exhibits in the Smaller Academic Library," College \& Research Libraries News 46 (July/Aug. 1985): 344-46; and Marjorie Markoff, "More than Information: A Popular Exhibit Shows the Personal Side of Books and Information," College \& Research Libraries News 49 (June 1988): 367-68.

4. Caswell, "Building a Strategy," 168.

5. Cynthia Peters et al., Public Services in Research Libraries: A Self-Study (Chicago: Newberry Library, Aug. 1984), 7.

6. Gundersheimer, "Two Noble Kinsmen," 101.

7. Caswell, "Building a Strategy," 168.

8. Gundersheimer, "Two Noble Kinsmen," 100.

9. A publication that briefly touches on a wider range of topics relating to exhibits is the result of a survey conducted by Mary Wyly, Exhibits in ARL Libraries, SPEC Kit 120 (Washington, D.C.: Assn. of Research Libraries, Office of Management Studies, Jan. 1986).

10. James Gregory Bradsher and Mary Lynn Ritzenthaler, "Archival Exhibits," in Managing Archives and Archival Institutions, ed. James Gregory Bradsher (Chicago: Univ. of Chicago Pr., 1989), 228 and 239.

11. Gail Farr Casterline, Archives \& Manuscripts: Exhibits (Chicago: Society of American Archivists, 1980), 8.

12. Ann E. Pederson and Gail Farr Casterline, Archives \& Manuscripts: Public Programs (Chicago: Society of American Archivists, 1982), 27.

13. Casterline, Archives \& Manuscripts: Exhibits, 8.

14. Ibid., 11.

15. Bradsher and Ritzenthaler, "Archival Exhibits," 233.

16. Pederson and Casterline, Archives \& Manuscripts: Public Programs, 27.

17. Nancy Allyn, Shawn Aubitz, and Gail F. Stern, "Using Archival Materials Effectively in Museum Exhibitions," American Archivist 50 (Summer 1987): 403.

18. See reviews in American Archivist 42 (Jan. 1979): 76-78; 43 (Winter 1980): 89-92; and 43 (Spring 1980): 221-24. Reviews have also appeared in The Journal of American History since 76 (Dec. 1989): 849-89).

19. For a recent example, see the discussion of the Smithsonian Institution's controversial exhibit, "The West as America." William H. Truettner, "The West and the Heroic Ideal: Using Images to Interpret History," Chronicle of Higher Education 38 (Nov. 20, 1991): B1-B2. Further discussion followed: see Mark McGinnis to the Editor, Chronicle of Higher Education 38 (Dec. 18, 1991): B6.

20. One of the most interesting examples of this type of study is Harris H. Shettel et al., Strategies for Determining Exhibit Effectiveness: Final Report (Pittsburgh: American Institutes for Research in the Behavioral Sciences, Apr. 1968).

21. Casterline, Archives \& Manuscripts: Exhibits, 11. 
22. See Ibid., 9-10 and 49-51; Bradsher and Ritzenthaler, "Archival Exhibits," 229-30.

23. Casterline, Archives \& Manuscripts: Exhibits, 22-23; Larry Klein, Exhibits: Planning and Design (New York: Madison Square Pr., 1986), 15. For a fascinating account of an interactive, participatory exhibit developed expressly to make a scholarly exhibit more accessible to a wider audience, see Barbara Franco, "Exhibiting Archival Material: A Method of Interpretation," in Museum News 58 (Sept./Oct. 1979): 55-59.

24. Casterline, Archives \& Manuscripts: Exhibits, 56; Shettel et al., Strategies for Determining Exhibit Effectiveness, 1; Franco, "Exhibiting Archival Material," 58-59.

25. Casterline, Archives \& Manuscripts: Exhibits, 10; Bradsher and Ritzenthaler, "Archival Exhibits," 232.

26. Casterline, Archives \& Manuscripts: Exhibits, 10. The Smithsonian's exhibit, "The West as America," challenged existing views by interpreting nontraditional sources in untraditional ways. Truettner, "The West and the Heroic Ideal," B1-B2. Refer also to the critique of the exhibit in John Alexander Williams to the Editor, Chronicle of Higher Education 38 (Dec. 18, 1991): B6.

27. Casterline, Archives \& Manuscripts: Exhibits, 14.

28. Bradsher and Ritzenthaler, "Archival Exhibits," 233.

29. On the symbolic or "icon" value of certain documents, see Allyn, Aubitz, and Stern, "Using Archival Materials Effectively," 403.

30. Or, in the words of another exhibit curator, "to provide a series of perceptual experiences" and "involve the visitor[s] in visual and manipulative activities" that will encourage them "to seek and discover concepts . . . for themselves," "to form their own conclusions." Franco, "Exhibiting Archival Material," 56.

31. Evaluating the conservation needs of materials for exhibit, and preservation requirements at the exhibit site, are discussed in Casterline, Archives \& Manuscripts: Exhibits, 19-22, and in Bradsher and Ritzenthaler, "Archival Exhibits," 235-37.

32. Casterline, Archives \& Manuscripts: Exhibits, 23.

33. Regarding labels: Casterline, Archives \& Manuscripts: Exhibits, 45; Bradsher and Ritzenthaler, "Archival Exhibits," 234-35.

34. Tim Crimmins, Kathy Dixon, Dana White, and Beverly Guy-Sheftall, Atlanta Heritage Row, Underground Atlanta, Atlanta, Georgia, permanent exhibit.

35. Chris Hardman, Etiquette of the Undercaste, Experimental Gallery, Arts and Industries Building, Smithsonian Institution, Washington, D.C., Feb. 14-Apr. 15, 1992. See also "Etiquette of the Undercaste," Floor Plan, Clipping File, Experimental Gallery, Arts and Industries Building, Smithsonian Institution, Washington, D.C.; Maria D. Vesperi, "Experience the Hell of Being Homeless-in a Museum," St. Petersburg Times (Feb. 16, 1992), 6D; Donald Garfield, "Experimental Gallery: Dying to Get In," Museum News 71 (May/June 1992): 24-25; Irvin Molotsky, "In a Museum, a Taste of Homelessness," New York Times (Feb. 4, 1992), A10.

36. Casterline, Archives \& Manuscripts: Exhibits, 48; Bradsher and Ritzenthaler, "Archival Exhibits," 238.

37. Casterline, Archives \& Manuscripts: Exhibits, 8.

38. Research notes, rejected materials, and items remaining after an exhibit are used by patrons of our library with surprising frequency. Suggestions on the contents of a permanent exhibit file are found in Bradsher and Ritzenthaler, Managing Archives, 239-40.

39. Eric Larrabee, Museums and Education: Final Report (Washington, D.C.: Smithsonian Institution, Sept. 10, 1967), 10 and 25.

40. G. Thomas Tanselle, Libraries, Museums, and Reading (New York: Book Arts Press, School of Library Science, Columbia University, 1991), 13. Tanselle provides a thought-provoking critique of many accepted library practices. An intriguing analysis of Tanselle's ideas is found in Sidney E. Berger, "The Preservation of Knowledge: A Response to G. Thomas Tanselle," Conservation Administration News 49 (Apr. 1992): 6-7 and 24.

41. Bruce Flanders, "Multimedia Programs to Reach an MTV Generation," American Libraries 23 (Feb. 1992): 135.

42. Ibid., 136.

43. The links between research and teaching are expressed as "the traditional scholarly underpinnings of the curriculum" in Chronicle of Higher Education 38 (Nov. 20, 1991): A1. On the renewed academic interest in teaching, see Carolyn J. Mooney, "Stanford 
Unveils Plan Designed to Elevate Status of Teaching," Chronicle of Higher Education 37 (Mar. 13, 1991): A15 and A19. See also Ann Hardie, "Colleges Put New Emphasis on Teaching," Atlanta Constitution (Mar. 25, 1991), D1 and D3. For new views of teaching and research, see Courtney Leatherman, "Definition of Faculty Scholarship Must Be Expanded to Include Teaching, Carnegie Foundation Says," Chronicle of Higher Education 37 (Dec. 5, 1990): A1 and A16-17.

44. Examples of interdisciplinary collaboration in research are described in Sam Zuckerman, "Astronomers, Archaeologists Debate Meaning of Ancient Markings in Pampas of Peru," Chronicle of Higher Education 34 (Feb. 24, 1988): A4-5 and A10; and Michael Moreau, "Taking a Dig at History" [linguists and archaeologists search for the origin of modern language in the Russian steppes], in Los Angeles Times (Mar. 19, 1992), E1 and E10. A surprising example of international cooperation between scientists and religious leaders to advance a public policy agenda is outlined in Carl Sagan, "Religion and Science, Old Antagonists, Forge a New Alliance to Avert a Common Danger," Parade Magazine (Mar. 1, 1992), 10-14.

45. A brief but interesting description of this teamwork is found in Helen Dalrymple, "The Making of an Exhibit," Library of Congress Information Bulletin 49 (Mar. 12, 1990): 105-106.

46. One of the most exciting research projects to be recently reported is a scholarly effort to present information about the excavation of the burial site and artifacts discovered in the tomb of the first emperor of China-"one of the most significant finds of this century." The project is directed by the associate dean of the Simmons College library school and includes on the research team a professor of anthropology, a curator of art, and a professor of Asian studies. They communicate the results of their research on two interactive videodiscs with film footage, images of artifacts, oral interviews with experts, and full text of publications. This project is at once scholarly, interdisciplinary, multimedia, and interactive. Beverly T. Watkins, "After 20 Years, Western Scholars Get Access to Information on a Key Archaeological Find," Chronicle of Higher Education 38 (Feb. 5, 1992): A21 and A23.

47. Caswell, "Building a Strategy," 168.

\section{CORRECTIONS}

The following two corrections apply to the article "Publication in College \& Research Libraries: Accepted, Rejected, and Published Papers, 1980-1991," by Peter Hernon, Allen Smith, and Mary Bailey Croxen (College \& Research Libraries 54 [July 1993]: 303-21):

The note for Table 1 was omitted; it stated that:

Some papers were rejected as articles but later accepted as "Research Notes."

Footnote 32 should read:

Data analysis did not proceed beyond 1990: for that year the authors only included manuscripts that had been submitted and for which the editor had rendered a decision. This accounts for the $\mathbf{2 4}$ articles mentioned in Table 1 for the year 1991. 


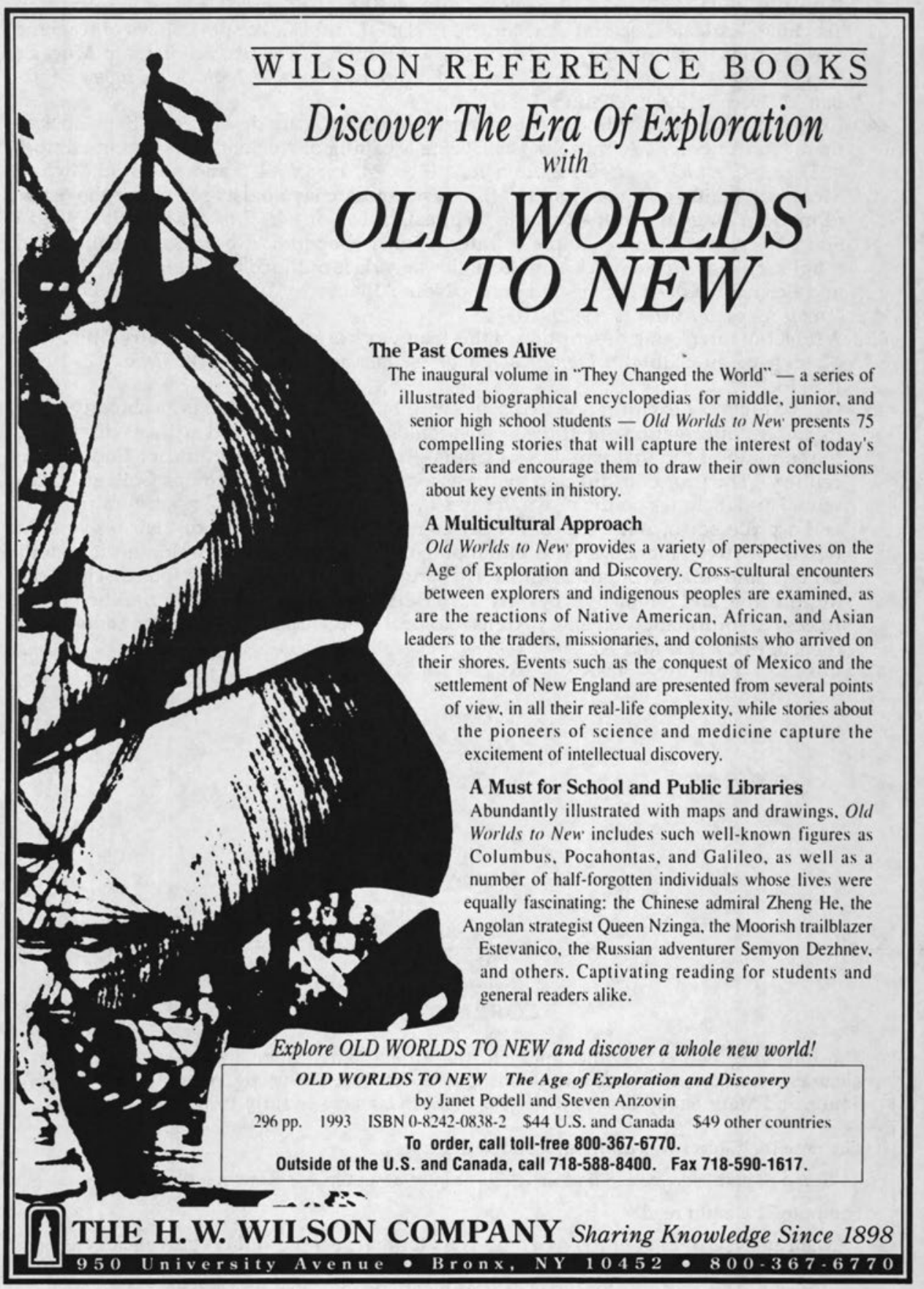

